\begin{tabular}{c} 
Tersedia online di: http://ejournal-balitbang.kkp.go.id/index.php/bawal \\
e-mail:bawal.puslitbangkan@ gmail.com \\
BAWAL WIDYA RISET PERIKANAN TANGKAP \\
Volume 10 Nomor 3 Desember 2018 \\
p-ISSN: 1907-8226 \\
e-ISSN: 2502-6410 \\
BAWAL \\
Nomor Akreditasi Kementerian RISTEKDIKTI: 21/E/KPT/2018 \\
\hline \hline
\end{tabular}

\title{
PENDUGAAN DAYA DUKUNG PERAIRAN UNTUK BUDIDAYA IKAN DALAM KERAMBA JARING APUNG DI WADUK PONDOK, NGAWI JAWA TIMUR
}

\section{CARRYING CAPACITY ESTIMATION FOR FISH CULTURE OF FLOATING NET CAGES IN PONDOK RESERVOIR, NGAWI EAST JAVA}

\author{
Siti Nurul Aida*1 dan Agus Djoko Utomo ${ }^{1}$ \\ 'Balai Riset Perikanan Perairan Umum dan Penyuluhan Perikanan, Jl. Gub H. Bastari No.8, Jakabaring, Seberang Ulu I. \\ Kota Palembang, Sumatera Selatan 30111, Indonesia \\ Teregistrasi I tanggal: 28 Nopember 2017; Diterima setelah perbaikan tanggal: 28 Januari 2019; \\ Disetujui terbit tanggal: 01 Februari 2019
}

\begin{abstract}
ABSTRAK
Waduk Pondok seluas 407 Ha berada di Ngawi Jawa Timur, beroperasi sejak 1995 dan merupakan waduk serbaguna. Kegiatan budidaya ikan dengan keramba jaring apung (KJA) di Waduk tersebut sudah berkembang, hingga mencapai 126 petak pada tahun 2016. Penelitian ini bertujuan untuk menganalisis tingkat kesuburan perairan, total fosfor yang terlepas dari KJA ke peraian dan mengestimasi daya dukung perairan untuk KJA. Tingkat kesuburan perairan dianalisa dengan nilai index status trofik (TSI). Estimasi daya dukung perairan untuk KJA menggunakan pendekatan model keseimbangan total fosfor $(\mathrm{P})$ yang terlepas ke parairan. Hasil penelitian menunjukkan bahwa perairan waduk Pondok sudah termasuk dalam katagori perairan eutrofik dengan nilai TSI 62,1.Total P yang terlepas ke perairan sebesar 15,04 kg ton ikan. Daya dukung perairan untuk KJA adalah 195,2 ton /tahun (130 petak KJA). Jumlah KJA di Waduk Pondok ada 126 petak (189 ton) atau sudah mendekati daya dukung perairan, sehingga jumlahnya tidak dapat ditambah lagi.
\end{abstract}

Kata Kunci: Daya dukung perairan; keramba jaring apung; waduk Pondok

\section{ABSTRACT}

Pondok Reservoir as large as 407 hectares is located in Ngawi, East Java. The Reservoir was functionally started in 1995, is a multipurpose reservoir. Fish culture in Pondok Reservoir in 2016 reached 126 cages. The aim of this research is to evaluate the trophic status, the total of phosphorus released into the waters from floating net cage, and carrying capacity of the reservoir for fish culture. Trophic status of reservoir was analyzed trough calculating the TSI (Trophic Status Index). A phosphorus mass balance model was used in assessing the carrying capacity of the reservoir. Research hypotesis in this research is Pondok reservoir has reached eutrophic status, and cages number in Pondok reservoir has alreday exceeds carriying capacity. Pondok reservoir have been categorized as eutrophic status, with the value of TSI 62.1. Total P released to the waters is $15.04 \mathrm{~kg} \mathrm{P} /$ ton of fish. The carrying capacity of Pondok Reservoir for fish culture is 195,2 ton / year (130 cages). The number fish culture in Pondok Reservoir is 126 cages (189 ton), has already approaching maximum number can not be added anymore.

Keywords: Carrying capacity: floating net cage; Pondok reservoir 


\section{PENDAHULUAN}

Pengembangan usaha budidaya ikan di Indonesia terus meningkat seiring dengan bertambahnya kebutuhan protein hewani oleh masyarakat. Waduk merupakan tipe perairan yang relatif tergenang (lentic) dan sering digunakan sebagai area budidaya ikan dalam bentuk keramba jaring apung (KJA).Usaha budidaya ikan dalam KJA di waduk dapat memberikan dampak positif bagi perekonomian masyarakat sekitarnya. Waduk Pondok dengan luas 407 hektar berada di Desa Gondang Kecamatan Bringin Kabupaten Ngawi Jawa Timur mulai beroperasi tahun 1995. Waduk serbaguna ini juga berfungsi sebagai irigasi, pembangkit tenaga listrik, sumber air minum, pariwisata, perikanan budidaya dan perikanan tangkap (Kasiyanti et al., 2013). Budidaya ikan dalam KJA di Waduk Pondok semakin berkembang, tahun 1999 sebanyak 10 petak meningkat menjadi 126 petak pada 2016 (Dinas Perikanan dan Peternakan Ngawi ,2016). Jenis ikan yang dipelihara adalah nila (Oreochromis niloticus), dengan pertimbangan laju pertumbuhannya cepat dan pemasarannya relatif mudah. Ukuran petak KJA umumnya seragam yaitu $7 \times 7 \times 5$ meter.

Perairan waduk mempunyai kemampuan yang terbatas untuk menerima beban, termasuk beban dari usaha budidaya ikan. Definisi daya dukung perairan untuk budidaya ikan menurut Gunkel et al. (2015) yaitu kemampuan perairan untuk mendukung sejumlah populasi ikan yang dibudidayakan di perairan tersebut. Apabila jumlah ikan yang dibudidayakan terlampau banyak melebihi daya dukung perairan maka akan menurunkan kualitas perairan, sehingga akan berdampak negatif terhadap organisme air yang ada di perairan tersebut termasuk ikan yang dibudidayakan.

Permasalahan utama usaha budidaya ikan dalam bentuk KJA di waduk yaitu sering menimbulkan pencemaran bahan organik dari sisa pakan dan kotoran ikan yang lolos ke perairan. Sisa pakan dan kotoran ikan akan terurai (dekomposisi) dan menyebabkan eutrofikasi (pengkayaan unsur hara), terutama unsur P (fosfor). Eutrofikasi disebabkan peningkapatan nutrien dan dapat menyebabkan blooming algae yaitu tanaman air yang dapat menyebabkan pesat menutupi permukaan air dan penurunan kualitas air (Beveridge, 1996).

Pengembangan budidaya ikan di Waduk harus sesuai dengan daya dukung perairan sehingga tidak memberikan bahan pencemaran yang berlebihan ke perairan (Syandri et al., 2016; Siagian, 2010). Bila jumlah ikan yang dibudidayakan tidak sesuai dengan daya dukung perairan maka sisa pakan dan kotoran ikan akan mencemari perairan dan dapat menyebabkan kematian ikan secara masal (Muhtadi et al., 2017). Untuk itu diperlukan penelitian tentang daya dukung perairan waduk untuk budidaya ikan.

Daya dukung perairan untuk KJA dapat diduga dengan keseimbangan fosfor di perairan, karena secara alami keberadaan fosfor di perairan merupakan faktor pembatas dan jumlahnya sangat sedikit. Apabila konsentrasi fosfor di perairan tinggi maka dapat dipastikan telah terjadi pencemaran bahan organik. Fosfor yang terlepas ke perairan dari sisa pakan dan kotoran ikan akan terurai dan akhirnya melepaskan kadar fosfor mencemari perairan menjadi pembatas daya dukung perairan untuk kehidupan organisme air. Hipotesis dalam penelitian ini yaitu perairan waduk Pondok sudah dalam kondisi eutrofik dan jumlah KJA sudah melebihi daya dukung perairan. Beberapa contoh akibat budidaya ikan yang tidak memperhatikan daya dukung perairan yaitu seperti yang terjadi di Danau Maninjau. Pada Oktober tahun 1997 terdapat kematian ikan dalam KJA sebesar 950 ton (Garno, 2002 dalam Syandri et al., 2016). Waduk Juanda pada Desember 1999 terjadi kematian ikan sebesar 900 ton (Krismono et al., 2008). Penelitian ini bertujuan untuk mengetahui daya dukung perairan untuk budidaya ikan dalam keramba jaring apung melalui analisis tingkat kesuburan perairan dan total fosfor yang terlepas ke peraian dari keramba jaring apung (KJA). Diharapkan hasil penelitian dapat memberikan masukan bagi pengelolaan usaha budidaya di Waduk, Ngawi Pondok Jawa Timur.

\section{BAHANDANMETODE}

Penelitian ini dilakukan di Waduk Pondok Kabupaten Ngawi Jawa Timur pada Pebruari hingga September 2016.

Parameter yang diamati meliputi: fisika kimia air (Tabel 1), tingkat kesuburan perairan, analisis proksimat pakan ikan, konversi pakan, total fosfor yang lolos ke perairan, daya dukung KJA di waduk, produksi ikan di KJA dan jumlah KJA di waduk. Disamping itu juga diperlukan data sekunder meliputi luasan dan kedalaman Waduk berdasarkan data dari Jasa Tirta I Kabupaten Malang.

Penentuan lokasi penelitian kualitas air dipilih mewakili tipe perairan waduk (Tabel 2 dan Gambar 1). 
Tabel 1. Parameter yang diamati dan Metode Analisis Sampel Table 1. Parameters observed and sample analysis $m$ ethod

\begin{tabular}{|c|c|c|c|}
\hline $\begin{array}{c}\text { Parameter/ } \\
\text { Parameters }\end{array}$ & $\begin{array}{c}\text { Satuan/ } \\
\text { Unit }\end{array}$ & $\begin{array}{l}\text { Peralatan/ } \\
\text { Equipment }\end{array}$ & Metode analisis/ Analysis method \\
\hline \multicolumn{4}{|l|}{ A. Kualitas air } \\
\hline 1. P- total perairan & $\mu \mathrm{g} / \mathrm{L}$ & Spectrophotometric. & $\begin{array}{l}\text { Persulfat Digestion Ascorbic Acid } \\
\text { (APHA, 2005) }\end{array}$ \\
\hline 2. Chlorophyl-a & $\mu \mathrm{g} / \mathrm{L}$ & Spectrophotometric. & $\begin{array}{l}\text { Determinasi Chlorophile panjang } \\
\text { gelombang } 664 \mathrm{~nm} \text { (Parsons et al.,1984 } \\
\text { in APHA, } 2005\end{array}$ \\
\hline 3. Suhu perairan & ${ }^{\mathrm{O}} \mathrm{C}$ & Termometer. & Insitu. (APHA, 2005) \\
\hline 4. Oksigen terlarut perairan & $\mathrm{mg} / \mathrm{L}$ & Do-meter & Insitu. (APHA, 2005) \\
\hline 5. Kecerahan & $\mathrm{Cm}$ & Piring Sechi. & Insitu. (APHA, 2005) \\
\hline \multicolumn{4}{|l|}{ B. Proksimat } \\
\hline 7 Kandungan total $\mathrm{P}$ dalam pakan ikan & $\%$ & Spectrophotometric & $\begin{array}{l}\text { UV-Vis. Ammonium vanadat dan } \\
\text { molibdat (APHA, 2005) }\end{array}$ \\
\hline 8 Kandungan total P dalam tubuh ikan & $\%$ & Spectrophotometric. & $\begin{array}{l}\text { UV-Vis. Ammonium vanadat dan } \\
\text { molibdat (APHA, 2005) }\end{array}$ \\
\hline
\end{tabular}

Tabel 2. Lokasi Penelitian di Waduk Pondok

Table 2. Research location at Pondok Reservoir

\begin{tabular}{|c|c|}
\hline Lokasi/Location & Keterangan/Remarks \\
\hline $\mathrm{A}$ & $\begin{array}{l}\text { Lokasi A (inlet Sungai Kenongo), dipilih sebagai lokasi pengamatan karena mewakili tipe } \\
\text { perairan inlet yang memasok air dari sungai ke waduk, tidak pernah mengalami kekeringan } \\
\text { walaupun saat musim kemarau dan sumber bahan organik yang masuk ke waduk dari daratan } \\
\text { sekitar desa Kenanga }\end{array}$ \\
\hline $\mathrm{B}$ & $\begin{array}{l}\text { Lokasi B (inlet sungai Gandu), dipilih sebagai lokasi pengamatan karena mewakili tipe perairan } \\
\text { inlet yang memasok air dari sungai ke waduk, tidak pernah mengalami kekeringan walaupun } \\
\text { saat musim kemarau dan merupakan sumber bahan organik dari desa Gandul. }\end{array}$ \\
\hline $\mathrm{C}$ & $\begin{array}{l}\text { Lokasi C (KJA), dipilih sebagai lokasi pengamatan karena mewakili tipe perairan yang banyak } \\
\text { terdapat KJA }\end{array}$ \\
\hline $\mathrm{D}$ & $\begin{array}{l}\text { Lokasi D (Tengah), dipilih sebagai lokasi pengamatan karena mewakili tipe perairan di tengah } \\
\text { waduk yang jauh dari tepian dan jauh dari KJA }\end{array}$ \\
\hline $\mathrm{E}$ & $\begin{array}{l}\text { Lokasi E (out let), dipilih sebagai lokasi pengamatan karena perairan tersebut dekat pintu keluar } \\
\text { merupakan akhir dari bahan bahan organik yang akan terbuang keluar waduk. }\end{array}$ \\
\hline
\end{tabular}

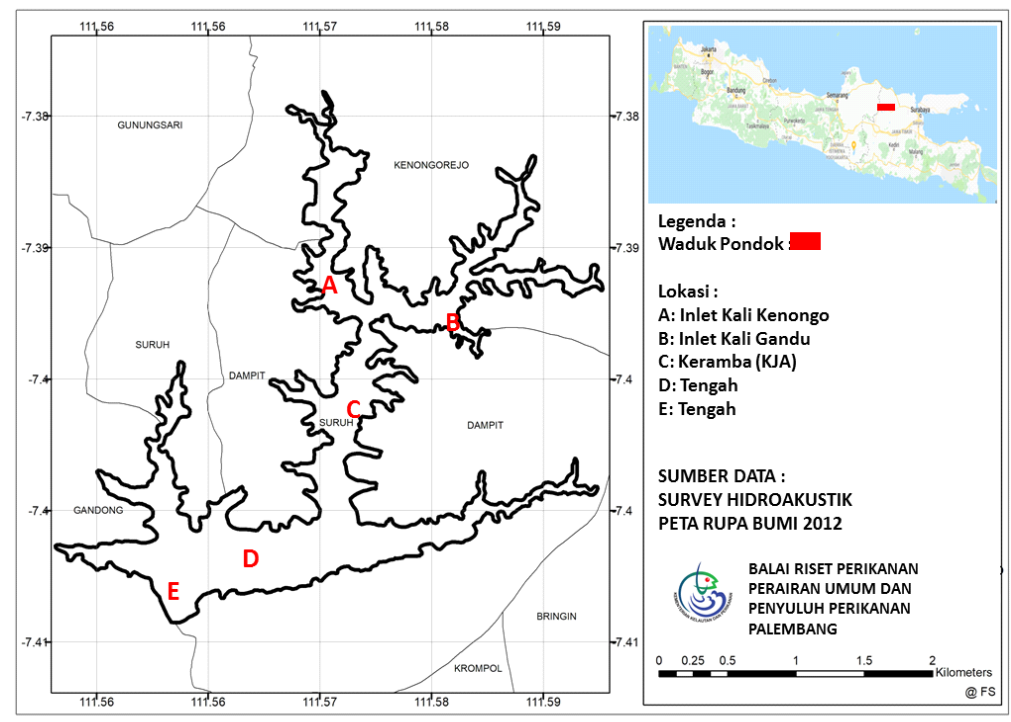

Gambar 1. Peta lokasi penelitian di Waduk Pondok.

Figure 1. Map of research location at Pondok Reservoir. 


\section{Penentuan Status Kesuburan Perairan}

Parameter penting untuk menentukan tingkat kesuburan perairan yaitu kandungan total fosfor, klorofil dan TSI (trophic Statu Index). Penentuan tingkat kesuburan perairan berdasarkan total P dan klorofil mengacu pada Novonty \& Olem (1994). Penentuaan kesuburan perairan berdasarkan nilai TSI mengacu pada Carlson (1977).

Menurut Novotny \& Olem (1994); perairan oligotrofik (kesuburan rendah) bila kandungan total fosfor kurang dari $10 \mu \mathrm{g} / \mathrm{L}$, mesotrofik (kesuburan sedang) bila kandungan fosfor total antara $10-35 \mu \mathrm{g} / \mathrm{L}$, eutrofik (kesuburan tinggi) bila kandungan fosfor total lebih dari $35-100 \mu \mathrm{g} / \mathrm{L}$, hipertrofik bila kandungan fosfor total > $100 \mu \mathrm{g} / \mathrm{L}$. Sedangkap tingkat kesuburan perairan berdasarkan klorofil adalah oligotrofik bila kandungan klorofil $<4 \mu \mathrm{g} / \mathrm{L}$, mesotrofik bila kandungan klorofil antara $4-10 \mu \mathrm{g} / \mathrm{L}$, eutrofik bila kandungan klorofil $>10 \mu \mathrm{g} / \mathrm{L}$.
Tingkat kesuburan perairan berdasarkan nilai index status trofik (trophic state index, TSI) menurut Carlson (1977), dengan rangkaian rumus sebagai berikut:

TSI $=($ TSI-SD+TSI-TP + TSI-Chl $) / 3$

TSI-SD $=60-14,41 * \operatorname{Ln}[S D]$, dimana SD = kecerahan air dalam meter ;

TSI-TP $=4,15+14,42 * \operatorname{Ln}[\mathrm{TP}]$, dimana TP $=$ total Fosfor dalam $\mu \mathrm{g} / \mathrm{Liter}$;

TSI-Chl $=30,6+9,81 * \operatorname{Ln}[\mathrm{Chl}]$, dimana $\mathrm{Chl}=$ kadar Khlorofil-a dalam $\mu \mathrm{g} /$ Liter.

Kriteria status trofik perairan dari Carlson diklasifikasikan dalam tingkat kesuburan sangat rendah, rendah (oligotrofik), sedang (mesotrofik), tinggi (eutrofik ringan- eutrofik berat) dan sangat tinggi (hyper eutrofik).

Tabel 3. Kategori status trofik berdasarkan pada Indeks Status Trofik Carlson Table 3. Trophic status catagory based on the Trophic Status Index' Carlson

\begin{tabular}{|c|c|c|}
\hline TSI & Status Trofik/ Trophic Status & Keterangan/ Remarks \\
\hline$<30$ & Ultraoligotrofik & $\begin{array}{l}\text { Kesuburan perairan sangat rendah. Air jernih, konsentrasi } \\
\text { oksigen terlarut tinggi sepanjang tahun dan mencapai lapisan } \\
\text { hypolimnion. }\end{array}$ \\
\hline $30-40$ & Oligotrofik & $\begin{array}{l}\text { Kesuburan perairan rendah, air jernih. Pada saat musim panas } \\
\text { pada danau yang dangkal dimungkinkan adanya pembatasan } \\
\text { anoksik pada lapisan hypolimnetik secara periodik. }\end{array}$ \\
\hline $40-50$ & Mesotrofik & $\begin{array}{l}\text { Kesuburan perairan sedang. Kecerahan air sedang, peningkatan } \\
\text { perubahan sifat anoksik di zona hypolimnetik selama musim } \\
\text { panas. }\end{array}$ \\
\hline $50-60$ & Eutrofik ringan & $\begin{array}{l}\text { Kesuburan perairan tinggi. Penurunan kecerahan air, zona } \\
\text { hypolimnetik bersifat anoksik, mulai terjadi masalah tanaman } \\
\text { air, hanya ikan-ikan yang bertoleransi terhadap air hangat. }\end{array}$ \\
\hline $60-70$ & Eutrofik sedang & $\begin{array}{l}\text { Kesuburan perairan tinggi. Didominasi oleh algae hijau-biru, } \\
\text { terjadi penggumpalan algae, masalah tanaman air sudah } \\
\text { ekstensif. }\end{array}$ \\
\hline $70-80$ & Eutrofik berat & $\begin{array}{l}\text { Kesuburan perairan tinggi. Terjadi bloming algae berat } \\
\text { sepanjang musim panas, seperti kondisi hypereutrofik. }\end{array}$ \\
\hline$>80$ & Hypereutrofik & $\begin{array}{l}\text { Kesuburan perairan sangat tinggi. Terjadi gumpalan algae, sering } \\
\text { terjadi kematian ikan pada saat musim panas. }\end{array}$ \\
\hline
\end{tabular}

\section{Perhitungan Total Pyang Lolos dari Keramba Jaring Apung}

Untuk menghitung total $\mathrm{P}$ dari sisa pakan yang lolos ke perairan diperlukan input data sebagai berikut (Beveridge 1996; Aertebjerg et al., 2001): (1). Kandungan total P dalam pakan ikan ("P.kn"), data ini diperoleh dari hasil pemeriksaan di laboratorium ( satuan: \% atau kg P/ ton pakan). (2). Kandungan total $\mathrm{P}$ dalam tubuh ikan ("P.ik"), data ini diperoleh dari hasil pemeriksaan di laboratorium (satuan \% atau $\mathrm{kg} \mathrm{P} /$ ton ikan). (3). Konversi pakan (FCR), data ini didapatkan dari catatan dan wawancara kepada enumerator pembudidaya ikan KJA.

Jumlah pembudidaya ikan di Waduk Pondok adalah 20 orang. Dipilih sebagai responden adalah orang yang mau bekerjasama mencatat data dan menangani langsung usaha budidaya ikan di Waduk Pondok, terpilih 4 orang yang memenuhi persayaratan tersebut. Perhitungan total $\mathrm{P}$ yang terlepas ke perairan (TLP) sebagai berikut (kg P/ton ikan): 
$\mathrm{TLP}=\mathrm{FCR} \times \mathrm{P} . \mathrm{kn}-\mathrm{P} . \mathrm{ik}$

\section{Perhitungan Daya Dukung Perairan untuk KJA}

Untuk mengetahui daya dukung perairan untuk KJA menggunakan pendekatan beban total-P di perairan, (Beveridge. 1996). Untuk menghitung daya dukung perairan menggunakan persamaan sebagai berikut:

$$
(\mathrm{DDP})=(\mathrm{TAL}):(\mathrm{TLP})
$$

\section{dimana:}

DPP = Daya dukung perairan untuk KJA (ton ikan/ tahun)

TLP = Total $\mathrm{P}$ yang terlepas di perairan selama budidaya (kg P/ton ikan)

TAL (Total beban P yang diperbolehkan $)=\mathrm{L}_{\text {fish }}$ x A. ( $\mathrm{kg}$ P/tahun)

$L_{f i s h}=\frac{\Delta(P) * Z * \rho}{\left(1-R_{f i s h}\right)}$

$T A L=\frac{\Delta(P) * Z * \rho}{\left(1-R_{f i s h}\right)} X \mathrm{~A}$

$D D P=\left(\frac{\Delta(P)^{*} Z^{*} \rho}{\left(1-R_{f i s h}\right)} X \mathrm{~A}\right): T L P$

$L_{\text {fish }}=$ beban P per satuan luas $\left(\mathrm{kg} / \mathrm{m}^{2} / \mathrm{th}\right)$

$\mathrm{A}=$ luas permukaan waduk $\left(\mathrm{m}^{2}\right)$

$\mathrm{Z} \quad=$ kedalaman rata rata perairan waduk $(\mathrm{m})$

$\rho$ (Laju pembilasan $)=\mathrm{Q}_{0} / \mathrm{V}$

$\mathrm{Q}_{0} \quad$ = rata - rata volume air yang keluar dari waduk/ tahun $\left(\mathrm{m}^{3} /\right.$ th $)$

$\mathrm{V} \quad=$ volume air waduk, pada $\left(\mathrm{m}^{3}\right)$

$\Delta(P)=(\mathrm{P}) \mathrm{f}-(\mathrm{P}) \mathrm{i}$
Pf = maksimum $\mathrm{P}$ yang dapat diterima di perairan waduk $\left(50 \mathrm{mg} / \mathrm{m}^{3}\right)$

$\mathrm{Pi}=$ rata rata konsentrasi $\mathrm{P}$ pada hasil penelitian $(40$ $\mathrm{mg} / \mathrm{m}^{3}$ )

$\mathrm{R}_{\text {fish }} \quad=$ proporsi $\mathrm{P}$ yang larut ke sediment.

$R_{f i s h}=x+\{(1-x) R\}$

$R=\frac{1}{\left(1+0.747 \rho^{0.507}\right)}$

$\mathrm{X}=$ merupakan proporsi total $\mathrm{P}$ secara permanen masuk ke dasar perairan. Menurut Beveridge (1996) kisaran besarnya $\mathrm{X}$ di perairan waduk dan danau antara $0,45-$ 0,55 .

\section{HASIL DAN BAHASAN \\ Hasil}

\section{Tingkat Kesuburan Perairan}

Sesuai dengan tujuan penelitian pertama yaitu menganalisis tingkat kesuburan perairan di Waduk Pondok. Beberapa parameter penting untuk menentukan tingkat kesuburan perairan yaitu kandungan fosfor, klorofil dan TSI.

a. Kesuburan perairan berdasarkan kandungan fosfor Kandungan total fosfor di Waduk Pondok (TP) ratarata $40,9 \mu \mathrm{g} / \mathrm{L} \pm 16,9 \mu \mathrm{g} / \mathrm{L}$ (Lampiran 1). Perairan waduk Pondok dilihat dari kandungan total fosfor rata-rata total P sudah masuk katagori perairan eutrofik.

b. Kesuburan perairan berdasarkan kandungan klorofil-a Kandungan total klorofil-a di perairan Waduk rata-rata $16,29 \mu \mathrm{g} / \mathrm{L} \pm 3,7 \mu \mathrm{g} / \mathrm{L}$. Perairan waduk Pondok dilihat dari kandungan rata-rata klorofil sudah masuk katagori perairan mesotrofik.

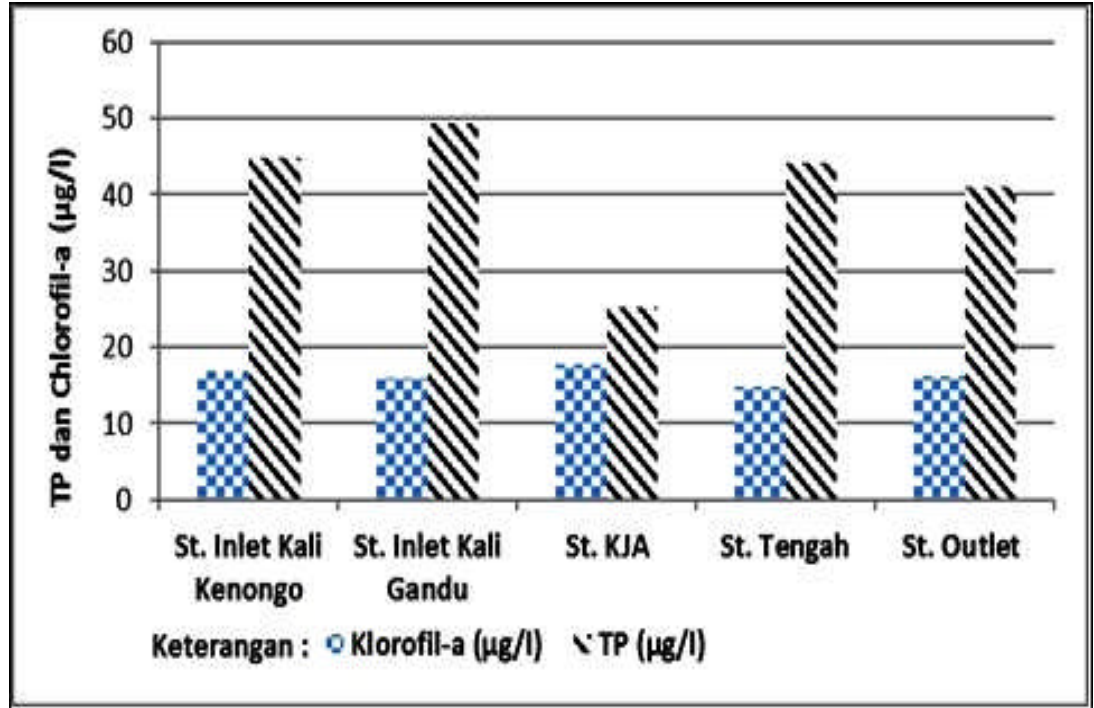

Gambar 2. Total fosfor dan chlorofile-a berdasarkan stasiun penelitian.

Figure 2. Total fosfor and chlorofile-a base on sampling location. 


\section{Kesuburan Perairan Berdasarkan Nilai TSI}

Hasil analisis seperti yang tersaji dalam Gambar 3, menunjukkan bahwa kisaran nilai TSI di perairan waduk
Pondok sebesar 62,1 $\pm 5,13$. Perairan waduk Pondok dilihat dari nilai rata-rata TSI sudah masuk katagori perairan eutrofik.

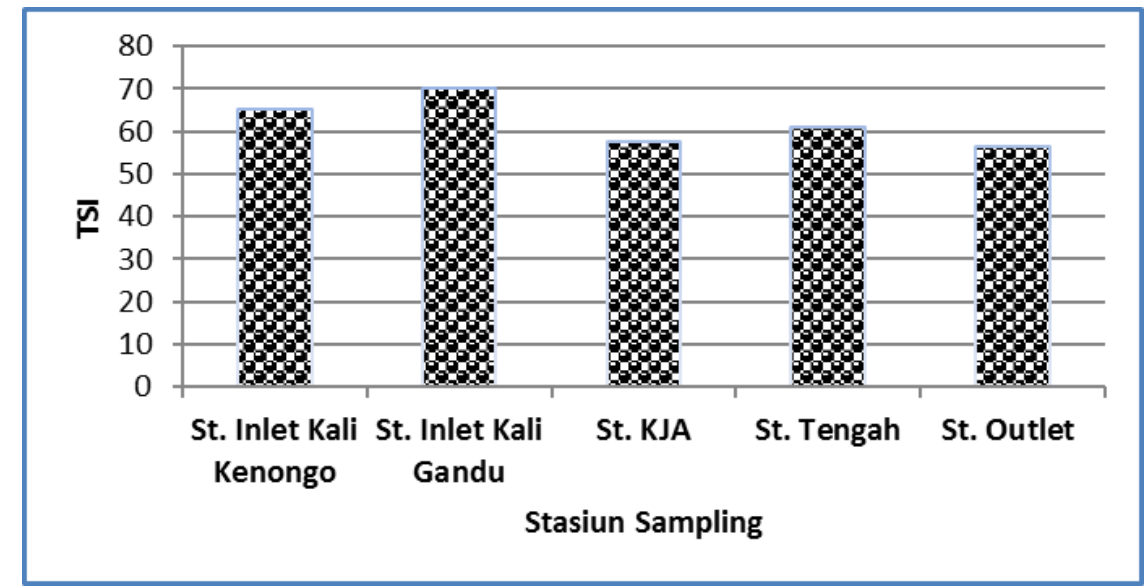

Gambar 3. Indek tingkat kesuburan di Waduk Pondok berdasarkan stasiun penelitian.

Figure 3. Trophic status index (TSI) at Pondok Reservoir base on sampling station.

\section{Perhitungan Total P yang Lolos ke Perairan (TLP)}

Tujuan penelitian ke dua yaitu menganalisis total $\mathrm{P}$ yang lolos ke perairan (TLP) dihitung berdasarkan pada persamaan (2). Parameter yang diperlukan dalam perhitungan tersebut adalah konversi pakan (FCR), kandungan total $\mathrm{P}$ dalam pakan dan total $\mathrm{P}$ dalam ikan.

a. Kandungan total P di dalam pakan dan ikan

Berdasarkan analisa proksimat pakan dan ikan di laboratorium, diperoleh kandungan total $\mathrm{P}$ disajikan dalam Tabel 3. Total $\mathrm{P}$ dalam pakan rata rata $1,53 \% \pm 0,01 \%$, Total P dalam ikan berkisar rata rata $0,73 \% \pm 0,01 \%$. b. Konversi pakan/ Food Conversion Ratio (FCR). Konversi pakan (FCR) pada budidaya ikan di Waduk Pondok rata rata 1,46 $\pm 0,06$ (Tabel 4).

c. Perhitungan total $\mathrm{P}$ yang lolos ke perairan (TLP)

Total P yang lolos ke perairan (TLP)dihitung berdasarkan pada persamaan (2) dari tiga para meter yang telah didapatkan yaitu konversi pakan (FCR), kandungan total $\mathrm{P}$ dalam pakan dan total $\mathrm{P}$ dalam ikan. Hasil perhitungan dari persamaan (2) didapatkan TLP $=15,04$ $\mathrm{kg}$ P/ton ikan.

Tabel 3. Kandungan total P dalam pakan dan ikan budidaya di Waduk Pondok

Table 3. Total P content in feed and fish Culture in Pondok Reservoir

\begin{tabular}{lcl}
\hline \multicolumn{1}{c}{$\begin{array}{c}\text { Sampel pakan dan ikan/Sample of } \\
\text { feed and fish }\end{array}$} & $\begin{array}{c}\text { Kandungan total P/ Total P content } \\
(\%)\end{array}$ & Catatan/Note \\
\hline A. Pakan & 1,52 & Pelet terapung \\
1. KJA responden I & 1,54 & Pelet terapung \\
2. KJA responden II & 1,53 & \\
\hline Rata rata & & Nila merah \\
\hline B. Ikan & 0,74 & Nila merah \\
1.KJA responden I & 0,72 & \\
\hline RJA responden II & 0,73 & \\
\hline
\end{tabular}


Tabel 4. Konversi pakan pada beberapa ikan budidaya di Waduk Pondok

Table 4. Food conversion ratio(FCR) on some fish culture at Pondok Reservoir

\begin{tabular}{|c|c|c|c|c|c|}
\hline No: & $\begin{array}{l}\text { Responden } \\
\text { /Respondent }\end{array}$ & $\begin{array}{c}\text { Jumlah pakan per } \\
\text { KJA/Amount of feed } \\
\text { per cage }(\mathrm{Kg})\end{array}$ & $\begin{array}{c}\text { Hasil Panen per } \\
\text { KJA/Harvest per } \\
\text { cage }(\text { Kg) }\end{array}$ & FCR & $\begin{array}{l}\text { Waktu/Duration } \\
\text { (Bulan/Month) }\end{array}$ \\
\hline 1 & I & 450 & 300 & 1,50 & 3 \\
\hline 2 & II & 450 & 300 & 1,50 & 3 \\
\hline 3 & III & 540 & 400 & 1,35 & 3 \\
\hline \multirow[t]{2}{*}{4} & IV & 450 & 300 & 1,50 & 3 \\
\hline & & FCR Rata rata & & 1,46 & \\
\hline
\end{tabular}

\section{Pendugaan Daya Dukung Perairan Untuk KJA}

Parameter yang diperlukan untuk menghitung daya dukung perairan yaitu kandungan fosfor di perairan (pi), total fosfor yang lolos ke perairan (TLP), kedalaman waduk (Z), volume air waduk (V) dan luas perairan Waduk (A). Hasil perhitungan dari persamaan 3 dan 4 didapatkan daya dukung perairan (DDP) untuk budidaya ikan di Waduk Pondok sebesar 195,2 ton/tahun. Berdasarkan wawancara dengan pembudidaya ikan, dalam satu petak KJA dapat memproduksi ikan rata-rata $1500 \mathrm{~kg} / \mathrm{tahun}$. Berdasarkan perhitungan jumlah KJA pada saat survei yaitu 126 petak KJA, setara dengan 189 ton sudah mendekati nilai daya dukung perairan yaitu 195,2 ton/tahun (130 petak KJA). Dengan demikian dapat disimpulkan bahwa keberadaan budidaya ikan dalam KJA di Waduk Pondok sudah mendekati nilai maksimum dan tidak dapat ditambah lagi.

Tabel 5. Parameter daya dukung perairan untuk budidaya ikan di Waduk Pondok.

Table 5. Parameters for carrying capacity of waters for fish culture at Pondok reservoir.

\begin{tabular}{lll}
\hline \multicolumn{1}{c}{ Paremeter / Parameters } & \multicolumn{1}{c}{ Nilai / Value } & \multicolumn{1}{c}{ Sumber / Sources } \\
\hline Luas waduk (A) & $407 \mathrm{ha}$ & Aida et al. $(2015)$ \\
Kedalaman rata-rata (Z) & $9,1 \mathrm{~m}$ & Aida et al. 2015 \\
Volume air waduk (V) & $28,04 \times 10^{6} \mathrm{~m}^{3}$ & Ditjen Sumberdaya Air (2010) \\
Rata rata volume air yang keluar dari waduk/tahun $\left(\mathrm{Q}_{0}\right)$ & $64,3 \times 10^{6} \mathrm{~m}^{3} / \mathrm{th}$ & Ditjen Sumberdaya Air (2010) \\
Laju pembilasan perairan $(\rho)$ & 2,28 & Ditjen Sumberdaya Air (2010) \\
Maksimum P yang dapat diterima di perairan waduk $(\mathrm{Pf})$ & $\left(50 \mathrm{mg} / \mathrm{m}^{3}\right)$ & Beveridge $(1996)$ \\
Kandungan P di perairan (Pi) & $40,9 \mathrm{mg} / \mathrm{m}^{3}$ & Hasil penelitian \\
Kandungan P dalam pakan (P.pakan) & $1,53 \mathrm{~kg} \mathrm{P/ton} \mathrm{pakan}$ & Hasil penelitian \\
Kandungan P dalam tubuh ikan (P.ikan) & $7,3 \mathrm{~kg} \mathrm{P/ton} \mathrm{ikan}$ & Hasil penelitian \\
Konversi pakan (FCR) & $1,46 \mathrm{~kg}$ P/ ton ikan. & Hasil penelitian \\
Total P yang lolos ke perairan (TLP) & $15,04 \mathrm{~kg}$ penelitian \\
Total beban P yang diperbolehkan (TAL) & $2936 \mathrm{~kg} \mathrm{P/th.}$ & Hasil penelitian \\
Daya dukung perairan untuk KJA (DDP) & 195,2 ton ikan/th. & Hasil penelitian \\
Jumlah KJA yang sesuai daya dukung & $130 \mathrm{petak}$ & Hasil penelitian \\
Jumlah KJA saat penelitian & $126 \mathrm{petak}$ & Hasil penelitian \\
\hline
\end{tabular}

Bahasan

\section{Tingkat Kesuburan Perairan}

Nilai rata-rata parameter untuk indikator kesuburan perairan di Waduk Pondok yaitu total $\mathrm{P}=40,9 \mu \mathrm{g} / \mathrm{L}$, klorofil$\mathrm{a}=16,29 \mu \mathrm{g} / \mathrm{L}$ dan TSI $=62,1$. Menurut klasifikasi tingkat kesuburan oleh Novotny \& Olem (1994), perairan waduk Pondok secara umum sudah termasuk katagori perairan eutrofik (kesuburan tinggi). Sumber fosfor secara alami sangat sedikit, sehingga fosfor merupakan faktor pembatas bagi kesuburan perairan (Utomo et al., 2010). Kadar fosfor yang tinggi di perairan merupakan indikasi bahwa ada sumber antropogenik, yaitu pencemaran dari aktivitas manusia (Utomo et al., 2011). Kegiatan yang menonjol di perairan waduk yaitu budidaya ikan pada KJA yang jumlahnya mencapai 189 ton (126 petak KJA). Perairan eutrofik akan mempunyai daya dukung yang rendah untuk KJA (Aida \& Utomo, 2011; Haryanto et al., 2014).

Keberadaan fosfor yang tinggi di perairan dapat menstimulir pertumbuhan fitoplankton, selanjutnya dapat menghambat penetrasi sinar matahari masuk ke perairan sehingga tidak menguntungkan bagi ekosistem perairan (Wibowo, 2014). Perairan Waduk Pondok berfungsi sebagai sumber air minum, ambang batas total fosfor perairan untuk kepentingan air minum tidak boleh melebihi $50 \mathrm{ìg} / \mathrm{L}$ (Beveridge, 1996; Byron et al., 2013). Aktivitas perikanan tidak boleh mengganggu fungsi utama waduk yaitu waduk sebagai sumber air minum.

Pencemaran bahan organik seperti pakan ikan ke perairan dapat menyebabkan kekeruhan sehingga nilai 
kecerahan menjadi rendah (Effendi, 2000). Secara umum nilai kecerahan Waduk Pondok kurang dari $1 \mathrm{~m}$. Hal ini menunjukkan perairan tersebut sudah dalam kondisi eutrofik (Lampiran 1). Kecerahan yang rendah dan kekeruhan yang tinggi dapat menyebabkan terganggunya sistem pernafasan dan daya lihat organisme akuatik, serta dapat menghambat penetrasi cahaya ke dalam air (White et al ., 2013).

Nilai TSI yang tinggi di Waduk Pondok disebabkan karena kadar total fospor yang tinggi, klorofil tinggi dan kecerahan yang rendah. Pada gambar 3 nilai rata rata TSI pada masing-masing lokasi berkisar antara 56,43 - 70,31. Secara umum masing masing lokasi sudah dalam kondisi eutrofik. Nilai TSI pada masing masing lokasi yang nilainya agak tinggi yaitu di daerah inlet (Gambar 3), hal tersebut disebabkan di daerah inlet nilai kecerahannya paling rendah yaitu 55-84 Cm (Lampiran 1). Kecerahan di inlet lebih rendah karena banyaknya partikel sedimentasi yang terbawa dari sungai masuk ke waduk (Utomo, 2013)

\section{Perhitungan Total P yang Lolos ke Perairan (TLP)}

Total P yang terlepas ke perairan dari budidaya dalam KJA di Waduk Pondok yaitu rata-rata 15,04 kg P/ton ikan, artinya dalam satu ton ikan yang dibudidayakan akan melepaskan fosfor ke perairan sebesar 15,04 kg P. Besarnya total $\mathrm{P}$ yang terlepas ke perairan sangat dipengaruhi oleh kandungan fosfor $(\mathrm{P})$ di dalam pakan dan konversi pakan (Welch, 2009., David et al., 2013). Kandungan total P dalam pakan cukup tinggi yaitu nilai rata rata $1,53 \%$. Menurut Nur dan Arifin (2004) dalam Ginting (2011) bahwa kandungan total $\mathrm{P}$ dalam pakan ikan sebaiknya tidak lebih dari $1 \%$ karena fosfor dalam ikan hanya diperlukan untuk memperkuat tubuh terutama bagian tulang, kandungan total $\mathrm{P}$ dalam tubuh ikan umumnya kurang dari $1 \%$.

Apabila pakan yang dimakan banyak mengandung P, maka akan dikeluarkan melalui kotoran ikan. Sehingga kandungan total $\mathrm{P}$ yang berlebihan di dalam pakan hanya akan mencemari perairan. Dengan asumsi kandungan $\mathrm{P}$ dalam pakan yang optimal adalah $1 \%$ (Ginting, 2011), maka dapat dibuat skenario apa bila kandungan total $P$ rata rata dalam pakan bisa dikurangi menjadi $1 \%$, maka total $\mathrm{P}$ yang lepas ke perairan baik yang berasal dari pakan maupun kotoran ikan akan menurun. Berdasarkan persamaan 2 (dua) maka dapat dibuat skenario kandungan total $\mathrm{P}$ dalam pakan bila diturunkan dari $1,53 \%$ menjadi $1 \%$ maka total P yang terlepas ke perairan (TLP) akan turun dari $15,04 \mathrm{~kg}$ $\mathrm{P}$ menjadi 7,7 kg P/ton ikan.

Berdasarkan persamaan 2 (dua) juga dapat dibuat skenario bahwa setiap penurunan kadar fosfor dalam pakan $0,1 \%$ akan mengakibatkan penurunan TLP (fosfor terlepas ke perairan) sebanyak 1,38 kg P/ton ikan. Jumlah Ikan yang dibudidaya sesuai daya dukung perairan yaitu 196,5 ton ikan, bila kadar fosfor berkurang $0,1 \%$ maka jumlah fosfor yang terlepas ke perairan akan berkurang 271,17 kg P. Volume air waduk Pondok ada 28,04 x $10^{6} \mathrm{~m}^{3}$ (Lampiran 1), dengan demikian penurunan kadar fosfor $0,1 \%$ akan menyebabkan penurunan TLP (fosfor lepas ke perairan) sebesar $9,67 \mathrm{mg} / \mathrm{m}^{3}$. Kadar fosfor di perairan waduk Pondok adalah $40,9 \mathrm{mg} / \mathrm{m}^{3}$ (Lampiran 1), agar perairan menjadi mesotrofik $\left(<35 \mathrm{mg} / \mathrm{m}^{3}\right)$ maka kadar fosfor dalam pakan harus dikurang $0,1 \%$ (dari $1,53 \%$ menjadi $1,43 \%$ ) sehingga kadar fosfor diperairan akan berkurang dari 40,9 menjadi $31,23 \mathrm{mg} / \mathrm{m}^{3}$. Agar perairan menjadi oligotrofik ( < $10 \mathrm{mg}$ / $\mathrm{m}^{3}$ ), maka kadar fosfor dalam pakan harus dikurangi 0,35 $\%$ (dari 1,53\% menjadi 1,18 \%) sehingga kadar fosfor di perairan menjadi $7,067 \mathrm{mg} / \mathrm{m}^{3}$.

Nilai TLP dari KJA di Waduk Pondok lebih tinggi bila dibanding nilai TLP dari KJA di Waduk Soedirman yaitu $12 \mathrm{~kg} \mathrm{P} /$ ton ikan. (Widyastuti, 2005). Hal tersebut disebabkan konfersi pakan budidaya ikan dalam KJA di Waduk Soedirman lebih efisien yaitu 1,3 sedangkan di Waduk Pondok 1,46. Tingginya nilai FCR akan berakibat pada tingginya sisa pakan yang terlepas ke perairan. Banyaknya sisa pakan yang terlepas ke perairan akan mempengaruhi banyaknya total $\mathrm{P}$ yang lepas ke perairan (David, 2014). Nilai FCR pada umumnya budidaya ikan Nila dalam KJA di Waduk/Danau yaitu berkisar antara 1,3 - 2,0. Untuk nilai FCR ikan Nila pada lingkungan yang terkontrol seperti Fibre Glass, bak semen, kolam adalah 1,2 - 1,5. Usaha perikanan KJA di Waduk lebih efisien dalam konsumsi pakan dibandingkan usaha budidaya ikan intensif lainnya. Sebagai contoh konversi pakan budidaya ikan di Waduk Saguling adalah 1,5 . Sedangkan konversi pakan budidaya ikan pada kolam air deras adalah $2-3,2$. (Haryono et al., 2001).

Perhitungan yang telah dilakukan pada total $\mathrm{P}$ yang lepas ke perairan (TLP) ada 15,04 kg P/ton ikan, maka satu petak KJA yang berisi 1,5 ton ikan/tahun akan melepaskan total P ke perairan sebesar 23,47 kg P/KJA. Menurut Midlen dan Redung (2000) dalam Marganof (2007) bahwa fosfor yang larut ke perairan adalah $10 \%$, sisanya mengendap di dasar perairan. Sisa pakan yang mengendap di dasar perairan akan membusuk mengalami proses dekomposisi sehingga akan mereduksi kandungan oksigen, sehingga kadar oksigen di dasar perairan akan lebih rendah (Sukimin,2008., Mhlanga et al., 2013). Apabila terjadi perubahan suhu permukaan lebih dingin maka akan terjadi pembalikan air (upwelling), lapisan dasar perairan yang miskin oksigen akan terangkat ke atas yang akan menyebabkan kematian masal bagi ikan di dalam keramba jaring apung.

Di dasar Waduk Pondok terdapat kadar oksigen yang sangat rendah, terutama di sekitar KJA dan bagian tengah waduk yaitu 0,1-0,3 mg/L (Aida et al., 2015). Peristiwa upwelling sering terjadi pada saat perubahan musim kemarau ke musim penghujan (Nopember-Desember) (Utomo et al., 2010). Menurut masyarakat pembudidaya 
ikan di Waduk Pondok, peristiwa kematian ikan dalam KJA sudah beberapa kali terjadi, terutama pada saat awal musim penghujan dan disertai angin kencang. Walaupun kematian ikan di Waduk Pondok tersebut belum begitu banyak seperti yang terjadi di Jawa Barat (Waduk Cirata, Waduk Juanda) namun sudah perlu dijaga kelestariannya.

\section{Pendugaan Daya Dukung Perairan untuk KJA}

Daya dukung perairan Waduk Pondok untuk KJA yaitu 195,2 ton/tahun atau 130 petak KJA. Saat ini sudah terdapat 126 petak KJA atau sudah mendekati nilai daya dukung perairan. Dengan demikian maka keberadaan jumlah KJA sudah maksimum dan tidak dapat ditambah lagi. Daya dukung perairan untuk KJA di Waduk Pondok termasuk rendah, hal tersebut disebabkan karena waduk tersebut sudah dalam kondisi eutrofik.

Beberapa hasil penelitian di beberapa waduk menunjukkan bahwa usaha budidaya sudah mencapai batas nilai daya dukung perairan. Sebagai contoh daya dukung perairan untuk KJA di Waduk Gajah Mungkur (Utomo, 2013) dan daya dukung perairan untuk KJA di Waduk Kedung Ombo (Utomo \& Aida, 2015).

Untuk menurunkan beban limbah P dari kegiatan KJA, maka tindakan yang paling tepat yaitu memperbaiki kualitas pakan agar kadar total $\mathrm{P}$ dalam pakan dapat dicerna oleh ikan (low polluting feed) serta memperbaiki manajemen pakan selama pemeliharaan ikan sehingga tidak menimbulkan beban limbah terhadap daya dukung perairan.

\section{KESIMPULAN}

Total fosfor yang terlepas ke perairan dari budidaya ikan dalam KJA adalah 15,04 kg P/ton ikan. Perairan Waduk Pondok sudah dalam kondisi eutrofik dengan nilai ratarata total $\mathrm{P}=41 \mu \mathrm{g} / \mathrm{L}$, klorofil $=16,29 \mu \mathrm{g} / \mathrm{L}$ dan TSI $=62,1$. Daya dukung perairan Waduk Pondok untuk budidaya ikan pada KJA adalah 195,2 ton/tahun setara dengan 130 petak KJA. Jumlah tersebut sudah optimum karena sudah mendekati nilai daya dukung perairan. Dengan demikian maka pengembangan budidaya ikan dalam KJA di Waduk Pondok dibatasi pada jumlah tersebut. Untuk mengendalikan beban limbah total P dari KJA ke lingkungan perairan waduk, maka diperlukan upaya pengembangan pakan ikan yang rendah polutan (low polluting feed) serta memperbaiki manajemen pakan agar pakan lebih efisien.

\section{PERSANTUNAN}

Karya tulis ini merupakan hasil kegiatan Penelitian pada Balai Penelitian Perikanan Perairan Umum Palembang yang dibiayai oleh dana APBN tahun anggaran 2016.
Penulis mengucapkan terimakasih kepada Dinas Peternakan dan Perikanan Kabupaten Ngawi, Jasa Tirta I Kabupaten Ngawi, enumerator pembudiaya ikan KJA khususnya Saudara Warsidi, Nardi, Jailani, Sutrisno, Edi Supriyanto; rekan rekan tim peneliti Taufiq Hidayah, M. Ali, Gatot Subroto dan Busyrol Waro yang telah banyak membantu dalam pelaksanaan penelitian.

\section{DAFTAR PUSTAKA}

Aertebjerg, G., Carstensen, J., \& Dahl, K. (2001). Eutrophication in Europe,s coastal water. (p. 155). European Environment Agency. Belgium.

Aida, S.N., \& Utomo, A.D. (2011). Tingkat kesuburan perairan di Waduk Kedung Ombo. BAWAL, 3(6), 415-422.

Aida, S.N., Utomo, A.D., Hidayah, T., Ali, M., Mentari, R.R. D., Kusuma, H., Rahmah, I. N., Subroto, G., \& Waroh, B. (2015). Sumber daya ikan dan lingkungan di Waduk Pondok dan Widas, Jawa Timur. Laporan Teknis/Akhir Tahun 2015. (p.161). Balai Penelitian Perikanan Perairan Umum Palembang.

APHA. (2005). Standard methods for the examinations of water and wastewater. (p.986). APHAinc, Washington DC.

Beveridge, M.C.M.(1996). Cage culture, second edition.(p.346). Fishing news books, Ltd. Fornham survey, England.

Byron, C.J., \& Costa-Pierce, B.A. (2013). Carrying capacity tools for use in the implementation of an ecosystems approach to aquaculture. In L.G. Ross, T.C. Telfer, L. Falconer, D. Soto \& J. Aguilar-Manjarrez, eds. Site selection and carrying capacities for inland and coastal aquaculture, pp. 87-101

Carlson, R.E. (1977). A trophic state index for lakes. Limnol. Oceanogr, V.22 (2).

David, G.S., Carvalho, E.D., Lemos, D., Silveira, A.N., \& Dall, A.S.M. (2015). Ecological carrying capacity for intensive tilapia (Oreochromis niloticus) cage aquaculture in a large hydroelectrical reservoir in Southeastern Brazil. J.Aquacultural Engineering, 66, 30-40.

David A.B. (2014). Aquaculture carrying capacity and water quality in Indonesian lakes and reservoirs. Aquacultura Indonesiana, 15 (2), 46-50.

Dinas Peternakan dan Perikanan Kabupaten Ngawi. (2016). Data produksi perikanan perairan umum daratan (p. 6). Kabupaten Ngawi.

Effendi, H. (2000). Telaahan Kualitas Air. (p.259). Jurusan MSP Fak. Perikanan dan Kelautan IPB Bogor. 
Ginting, O. (2011). Studi korelasi kegiatan budidaya ikan dalam keramba jaring apung dengan pengkayaan nutrien dan Chlorofil-a di Danau Toba. Tesis Program Pasca Sarjana. Fakultas Matematik dan Ilmu Pengetahuan Alam. Universitas Sumatera Utara. Medan.

Gunkel, G. Matta, E., Selge, F., Moraes, G., Silva, N.d., \& Sobral, M.C. (2015). Carrying capacity limits of net cage aquaculture in Brazilian Reservoirs. J.Revista Brasileira de Ciências Ambientais (RBCIAMB). (36), 128-144.

Haryono., Khoir, J., Syamsir., \&Erwanto, T. (2001). Pertumbuhan ikan nila gift yang diberi pakan dengan sumber protein hewani yang berbeda. (p.60). Zoologi-Biologi LIPI. Bogor.

Haryanto, H., Thamrin., \& Sukendi. (2014). Trophic status and capacity of the wastewater pollution load floating net cages fish culture in Koto Panjang reservoirs. Journal of Environmental Science, 8 (2), 131-145.

Kasiyanti, J., Nugroho, H., \& Dwijoyanto. (2013). Kajian penanggulangan banjir kali Widas Kabupaten Nganjuk Provinsi Jawa Timur. Tesis. Program Studi Magister Pengelolaan Sumber Daya Air. Institut Teknologi Bandung.

Krismono., Astuti, L.P., \& Warsa, A. (2008). Evaluation of water quality at Ir. H. Djuanda Reservoir, Jatiluhur. Proceding, international conference on Indonesian inland waters I. (p.105-109). Research Institute for Inland Fisheries Palembang.

Marganof. (2007). Model pengendalian pencemaran di danau Maninjau Sumatera Barat. Disertasi. Pasca Sarjana IPB. Bogor.

Mhlanga, L., Mhlanga, W., \& Mwera, P. (2013). The application of a phosphorus mass balance model for estimating the carrying capacity of Lake Kariba. Turk $J$ Vet Anim Sci, (37), 316-319.

Muhtadi,A., Yunasfi, M., Ma'rufi., \& Rizki,A. (2017). Morfometri dan daya tampung beban pencemaran Danau Pondok Lapan di Kabupaten Langkat, Sumatra Utara. Jurnal Oseanologi dan Limnologi di Indonesia (OLDI), 2(2), 49-63.

Novotny, V., \& Olem, H. (1994). Water Quality, prevention, identification, and management of diffuse polluition. (p.1054). Van Nostrans Reinhold. New York.

Sukimin, S. (2008). The application of phosphourus loading model estimating the carriying capacity for cage culture and Its productivity of Saguling Reservoir, West Java, Indonesia. (pp. 99-104). Proceeding, International Conference on Indonesian Inland Waters. Research Institute for Inland Fisheries Palembang.
Syandri, H., Azrita., \& Niagara. (2016). Trophic status and load capacity of water pollution waste fish culture with floating net cages in Maninjau Lake, Indonesia. Eco. Env. \& Cons, 22(1), 469-476.

Siagian, M. (2010). Daya dukung waduk PLTA Koto Panjang Kampar Provinsi Riau. Jurnal Perikanan dan Ilmu Kelautan, 15(1), 25 - 38.

Utomo, A.D. (2010). Pendugaan daya dukung perairan untuk budidaya ikan pada keramba jaring apung di Waduk Kuto Panjang Riau. Prosiding. Seminar nasional tahunan VII. 7(1), 1-8. Jurusan Perikakan Kelautan UGM dan BRKP. Jogyakarta.

Utomo, AD., Ridho, M.R., Putranto, D.DA., \& Saleh, E. (2010). The water quality assessment at Gajah Mungkur Reservoir. Proceeding. International Conference on Indonesian Inland Waters II. (P.123-133). Research Institute for Inland Fisheries.

Utomo, AD., Ridho, M.R., Putranto, D.DA., \& Saleh, E. (2011). Keanekaragaman plankton dan tingkat kesuburan perairan di Waduk Gajah Mungkur. BAWAL. Jakarta, 3(6), 415-422.

Utomo, P., Hasanah, P., \& Moko, I.G. (2011). Pengaruh pemberian pakan berbeda terhadap konversi pakan dan pertumbuhan ikan Mas (Cyprinus carpio) di keramba jaring apung. Jurnal Akuakultur Indonesia IPB Bogor, 4(2), 49-52.

Utomo, A.D. (2013). Penentuan daya dukung keramba jaring apung di Waduk Gajah Mungkur. Disertasi. Program Studi Ilmu Lingkungan Universitas Sriwijaya Palembang.

Welch, E.B. (2009). Phosphorus reduction by dilution and shift in fish species in Moses lake. International Journal. Lake and Reservoir Management. Taylor and Francis. London, 25(3), 276-283.

White, P., Phillips, M.J., \& Beveridge, M.C.M. (2013). Environmental impact, site selection and carrying capacity estimation for small-scale aquaculture in Asia. Site Selection and Carrying Capacities for Inland and Coastal Aquaculture. (p. 231-251). FAO-Fisheries and Aquaculture Departement, Rome-Italy.

Wibowo, H. (2014) Tingkat eutrofikasi Rawa Pening dalam kerangka kajian produktivitas primer fitoplankton. Tesis. Pasca Sarjana Universitas Diponegoro. Semarang.

Widyastuti, E. (2005). Model pengelolaan berkelanjutan budidaya ikan dalam keramba jaring apung di waduk PB Soedirman. Disertasi. Pasca Sarjana IPB. Bogor. 
Lampiran 1. Kualitas air di Waduk Pondok

Appendix 1. Water Quality at Pondok Reservoir

\begin{tabular}{cccccc}
\hline \multirow{2}{*}{ Lokasi/Location } & \multicolumn{5}{c}{ Parameter/Parameters } \\
\cline { 2 - 6 } & Suhu $\left({ }^{\circ} \mathbf{C}\right)$ & $\begin{array}{c}\text { Kecerahan } \\
(\mathbf{C m})\end{array}$ & DO $(\mathbf{m g} / \mathbf{l})$ & $\begin{array}{c}\text { Klorofil-a } \\
(\mathbf{m g} / \mathbf{m} \mathbf{3})\end{array}$ & TP $(\boldsymbol{\mu g} / \mathbf{L})$ \\
\hline St. Inlet Kali Kenongo & $29-34$ & $55-84$ & $6,17-9,52$ & $9.52-19.28$ & $34-55,9$ \\
& & & & $10.71-17.85$ & $22,4-74$ \\
St. Inlet Kali Gandu & $29,6-32$ & $50-83$ & $6,7-7,8$ & $10.71-20.23$ & $14,4-35,2$ \\
St. Keramba & $28-31,5$ & $72-108$ & $6,38-7,9$ & $13.09-15.47$ & $27,7-57,9$ \\
St. Tengah & $28-31,5$ & $72-108$ & $6,38-7,9$ & 11,9 \\
St. Outlet & $28-32$ & $80-112$ & $6,8-7,6$ & $10.71-21.42$ & $11-56,7$ \\
Rerata & 30.15 & 80.9 & 7.157 & 16.294 & 40,9 \\
\hline
\end{tabular}


Lampiran 2. Perhitungan Daya Dukung Perairan Untuk Budidaya Ikan pada Keramba Jaring Apung di Waduk Pondok Appendix 2. The Calculation of Carrying Capacity for Fish Culture on Floating Net Cages at Pondok Reservoir

a). Perhitungan total P yang lolos ke perairan (TLP), menurut persamaan (2)

TLP = FCR x P.pakan - P.ikan

FCR = konversi pakan (ton pakan/ton ikan), adalah 1,46 (Tabel 4)

P.pakan $=1,53 \mathrm{~kg} \mathrm{P} /$ ton pakan $($ Tabel 3)

P.ikan $=7,3 \mathrm{~kg} \mathrm{P} /$ ton ikan (Tabel 3)

TLP $=1,46 \times 15,3 \mathrm{~kg} \mathrm{P} /$ ton ikan $-7,3 \mathrm{~kg}$ P/ton ikan

$=22,34 \mathrm{~kg}$ P/ton ikan $-7,3 \mathrm{~kg} \mathrm{P} /$ ton ikan

$=15,04 \mathrm{~kg} \mathrm{P} /$ ton ikan.

b). Perhitungan total beban P yang diperbolehkan (TAL), menurut persamaan (4) dan (5)

$$
\begin{aligned}
L_{f i s h} & =\frac{\Delta(P) * Z * \rho}{\left(1-R_{f i s h}\right)} \\
T A L & =\frac{\Delta\{P\}^{*} Z * \rho}{\left(1-R_{f i s h}\right)} X \mathrm{~A}
\end{aligned}
$$

$A=$ Luas permukaan perairan waduk (407 ha atau 4,07x $\left.10^{6} \mathrm{~m}^{2}\right)$

$\mathrm{Z}=$ Kedalaman rata rata perairan waduk $(9,1 \mathrm{~m})$

$\mathrm{Q}_{0}=$ Rata rata volume air yang keluar dari waduk/tahun $\left(64,3 \times 10^{6} \mathrm{~m}^{3} / \mathrm{th}\right)$

$\mathrm{V}=$ Volume air waduk $\left(28,04 \times 10^{6} \mathrm{~m}^{3}\right)$

$\rho$ (Laju pembilasan $)=\mathrm{Q}_{0} / \mathrm{V}$ yaitu 2,29

$\Delta[\mathrm{P}]=[\mathrm{P}] \mathrm{f}-[\mathrm{P}] \mathrm{i}$

$\mathrm{Pf}=$ Maksimum $\mathrm{P}$ yang dapat diterima di perairan waduk $\left(50 \mathrm{mg} / \mathrm{m}^{3}\right)$

$\mathrm{Pi}=$ Rata rata konsentrasi $\mathrm{P}$ pada hasil penelitian $\left(40,9 \mathrm{mg} / \mathrm{m}^{3}\right)$

$\mathrm{R}_{\text {fish }}=$ Proporsi P yang larut ke sediment .

$$
\begin{aligned}
& R_{f i s h}=x+\{(1-x) R\} \\
& R=\frac{1}{\left(1+0.747 \rho^{0.507}\right)}
\end{aligned}
$$

yaitu $\mathrm{R}=0,48$

$\mathrm{X}=$ merupakan proporsi total $\mathrm{P}$ secara permanen masuk ke dasar perairan, besarnya untuk perairan waduk 0,5 (Beveridge, 1996).

$\mathrm{R}_{\text {fish }}=0.5+((1-0.5) 0,48)$ yaitu $\mathrm{R}_{\text {fish }=} 0,74$

TAL $=(50-40,9) \mathrm{mg} / \mathrm{m}^{3} \times 9 \mathrm{~m} \times 2,29 \times 4,07 \times 10^{6} \mathrm{~m}^{2}:(1-0,74)$

$\mathrm{TAL}=2936 \times 10^{6} \mathrm{mg} \mathrm{P} / \mathrm{th}=2936 \mathrm{~kg} \mathrm{P} / \mathrm{th}$

c). Perhitungan daya Dukung perairan untuk KJA (DDP) menurut persamaan (6)

$$
\mathrm{DPP}=\mathrm{TAL} / \mathrm{TLP}
$$

TAL $=2936 \mathrm{~kg} \mathrm{P} /$ th dan TLP $=15,04 \mathrm{~kg} \mathrm{P} /$ ton ikan

$\mathrm{DDP}=(2936 \mathrm{~kg} \mathrm{P} / \mathrm{th}):(15,04 \mathrm{~kg} \mathrm{P} /$ ton ikan $)=195,2$ ton ikan $/ \mathrm{th}$.

Dengan asumsi satu petak KJA menghasilkan ikan rata-rata $1500 \mathrm{~kg} /$ tahun maka daya dukung perairan untuk KJA adalah 130 petak KJA. Sedangkan di Waduk Pondok sudah terdapat 126 petak KJA, maka keberadaan jumlah KJA di Waduk Pondok sudah optimum tidak dapat ditambah lagi. 